\title{
The Analysis of Factors of the Vice President Secretariat Organization's Performance in Supporting the Vice President
}

\author{
Effi Ratna Furkon* \& Eko Prasojo \\ Master of Administration and Public Policy Study Program, Faculty of Administrative Sciences, \\ Universitas Indonesia, Indonesia \\ Received: 31 May 2021; Reviewed: 31 May 2021; Acepted: 22 July 2021 \\ *Email: effirf@gmail.com
}

\begin{abstract}
The implementation of the Vice President's broad and dynamic duties must, of course, be supported by good performance tools. As the Vice President's first support system, the Vice President's Secretariat (Setwapres) position was very strategic to improve organizational performance. The purpose of the study was to analyze the performance factors of the Vice President Secretariat in providing support to the Vice President from the perspective of the McKinsey 7S Framework. This research was descriptive research with a qualitative approach. The study used primary data and secondary data. Primary data sources using the interview method. Secondary data sources using relevant document data search. All data were presented descriptively and analyzed through data reduction, data presentation, and verification. The results of the study indicated that the supporting factors were (1) a structure where there was a clear division of tasks and functions as well as good coordination; (2) a style in which democratic leadership made communication work well with direct involvement of the leadership in carrying out tasks; (3) the existence of shared values accompanied by internalization and strengthening activities. The inhibiting factors were: (1) a strategy in which several activity programs were not by the Vice President's priority program; (2) a system where the implementation of SOPs was not entirely appropriate; (3) staff where the placement was not by the educational background; (4) skills that had not been supported by appropriate training.
\end{abstract}

Keywords: factor; performance; organization; Vice President.

How to Cite: Furkon, ER \& Prasojo, E. (2021). Analysis of Factors of the Vice President's Secretariat in Supporting the Vice President. Journal of Public Administration (Public Administration Journal). 11(2):111-120. 


\section{INTRODUCTION}

Article 4 paragraph (2) of the 1945 Constitution states that one vice president assists the President in carrying out his obligations. It said that constitutionally the Vice President acts as an assistant to the President in administering the government. The implementation of the duties of the Vice President is based on three types, namely delegative assignments based on statutory regulations; selection of directives according to the President's orders in cabinet meetings, limited meetings, or in-person; and projects from the Vice President's initiative. This has an impact on the breadth of strategic issues being handled as well as the high level of dynamics of the Vice President's activities.

Several strategic issues handled by the Vice President in 2015-2019 include poverty alleviation, National Bureaucratic Reform, Regional Autonomy, tourism, prevention of stunting, and so on. These programs range from the economy, sports, tourism to world peace. While the number of activities of the Vice President in 20152019 is as follows.

Table 1. Number of Vice President Activities in 2015-2019

\begin{tabular}{lccccc}
\hline \multicolumn{1}{c}{ Vice President Activities } & \multicolumn{5}{c}{ Number of Activities } \\
\cline { 2 - 6 } State Guest Visit & 2015 & 2016 & 2017 & 2018 & 2019 \\
Overseas Visits & 3 & 4 & 6 & 5 & 7 \\
Working Visit to the Region & 10 & 7 & 9 & 10 & 9 \\
Events at the Center (Jakarta) & 65 & 49 & 78 & 99 & 75 \\
Honorary Visit/Audience & 489 & 418 & 406 & 344 & 460 \\
Total & 544 & 410 & 395 & 361 & 447 \\
\hline
\end{tabular}

Source: 2019 Presidential Secretariat Performance Report

Table 1 shows an average of one day the Vice President can attend more than one event. The implementation of the Vice President's broad and dynamic duties must be supported by good performance tools. Minister of State Secretary Regulation Number 3 of 2015 states that the Vice President Secretariat is an organization that is responsible for providing housekeeping and protocol support as well as policy analysis to the Vice President. As an organization attached to the Vice President, the Vice President Secretariat must, of course, improve organizational performance in order to realize excellent service.

Organizational performance by(Daft 2010)is the organization's ability to achieve its goals using resources effectively and efficiently. Organizational performance indeed cannot be separated from the influencing factors. Peters \& Waterman (2004) argue that in addition to the structural and strategic elements, the humanism factor also needs to be considered. This concept is known as the McKinsey 7S Framework. It consists of seven variables which are grouped into complex categories (strategy, structure, system) and soft categories (style, skill, staff, and shared values).

In its development, McKinsey's 7Frameworkrk is not only for profitoriented organizations but has been widely used by public organizations. Study (Alshaher, 2013)using the 7S McKinsey Framework in public organizations to assess the readiness of universities in Iraq to implement e-learning systems. Meanwhile, in Indonesia, Mckinsey's 7Frameworkrk is used to improve the performance of health centers in Sampang District(Masfi et al., 2020). The version of the Vice President Secretariat for 20152019 is as follows. 
Table 2. Performance of Vice President Secretaria (Setwapres) 2015-2019

\begin{tabular}{|c|c|c|c|c|c|c|c|c|c|c|c|c|}
\hline \multirow[t]{2}{*}{ No } & \multirow{2}{*}{$\begin{array}{l}\text { Strategic } \\
\text { target }\end{array}$} & \multirow[t]{2}{*}{ KPI } & \multicolumn{2}{|c|}{2015} & \multicolumn{2}{|c|}{2016} & \multicolumn{2}{|c|}{2017} & \multicolumn{2}{|c|}{2018} & \multicolumn{2}{|c|}{2019} \\
\hline & & & Target & $\begin{array}{c}\text { Realizat } \\
\text { ion }\end{array}$ & Target & $\begin{array}{c}\text { Realizat } \\
\text { ion }\end{array}$ & Target & $\begin{array}{c}\text { Realizat } \\
\text { ion }\end{array}$ & Target & $\begin{array}{c}\text { Realizat } \\
\text { ion }\end{array}$ & Target & $\begin{array}{c}\text { Realizat } \\
\text { ion }\end{array}$ \\
\hline 1 & $\begin{array}{l}\text { Increased } \\
\text { technical } \\
\text { support, } \\
\text { administrati } \\
\text { on, and } \\
\text { analysis of } \\
\text { state } \\
\text { government } \\
\text { affairs in } \\
\text { supporting } \\
\text { the } \\
\text { implementat } \\
\text { ion of the } \\
\text { vice } \\
\text { president's } \\
\text { duties } \\
\end{array}$ & $\begin{array}{l}\text { IKU 1: } \\
\text { The } \\
\text { percentage } \\
\text { of policy } \\
\text { analysis } \\
\text { followed up } \\
\text { by the vice } \\
\text { president in } \\
\text { assisting } \\
\text { the } \\
\text { President }\end{array}$ & $100 \%$ & $100 \%$ & $100 \%$ & $100 \%$ & $100 \%$ & $100 \%$ & $100 \%$ & $100 \%$ & $100 \%$ & $100 \%$ \\
\hline 2 & $\begin{array}{l}\text { Guaranteed } \\
\text { delivery of } \\
\text { quality } \\
\text { housekeepin } \\
\text { g and } \\
\text { protocol } \\
\text { services to } \\
\text { the vice } \\
\text { president }\end{array}$ & $\begin{array}{l}\text { IKU 2: } \\
\text { The } \\
\text { percentage } \\
\text { of smooth } \\
\text { support for } \\
\text { the } \\
\text { provision of } \\
\text { household } \\
\text { services to } \\
\text { the vice } \\
\text { president } \\
\text { IKU 2: } \\
\text { The index of } \\
\text { the } \\
\text { smoothness } \\
\text { of providing } \\
\text { support for } \\
\text { household } \\
\text { services to } \\
\text { the vice } \\
\text { president }\end{array}$ & $100 \%$ & $100 \%$ & 4.33 & 5.16 & 4.33 & 5.30 & 4.44 & 5.32 & 4.44 & 5.33 \\
\hline & & $\begin{array}{l}\text { IKU 3: } \\
\text { The } \\
\text { percentage } \\
\text { of smooth } \\
\text { support for } \\
\text { providing } \\
\text { protocol } \\
\text { services to } \\
\text { the vice } \\
\text { president } \\
\text { IKU 3: } \\
\text { The index of } \\
\text { smoothness } \\
\text { in providing } \\
\text { support for } \\
\text { protocol } \\
\text { services to } \\
\text { the vice } \\
\text { president }\end{array}$ & $100 \%$ & $100 \%$ & 4.33 & 5.13 & 4.33 & 5.16 & 4.44 & 5.28 & 4.44 & 5.20 \\
\hline
\end{tabular}

Source: 2019 Presidential Secretariat Performance Report

Table 2 shows the performance of 2 has decreased for three consecutive years. While performance 3 , although it increases every year, in 2019 , the increase is not too significant, which is only $0.01 \%$. The Vice President Secretariat Performance Report mentions the challenges faced, including the high dynamics of the Vice President's activities, including sudden assignments from the President, changes in the Vice President's preferences for the presentation of policy analysis 
materials/reports, as well as differences in the characteristics of the Vice President. Meanwhile, the existing problem is that the use of information and communication technology (ICT) is not yet optimal, where not all work units have an information system for storing data and knowledge in the process of preparing policy analysis, thus affecting timeliness, content,

In this regard, (Robbins \& Judge, 2015) (Fahrudin et al., 2019)said a performance improvement is a form of improving the ability to increase the effectiveness of the organization is adjusting to changes in the environment and behavior of members. This is because the dynamic environment can not be avoided by the organization(Dewi \& Kurniawan, 2019). As in the era of digital transformation, private and public organizations must change their management practices (Matt, Hess, \& Benlian, 2015) (Kocaoglu \& Demir, 2019). Whereas(Garbrah et al., 2013) mentions that many public organizations have improved their management strategies through the implementation of the private sector concept. (Peters \& Waterman, 2004) said that every innovative approach to organizing includes the seven variables of McKinsey's 7Frameworkrk.

Based on the above background, the focus of the research problem is how the performance factors of the Vice President Secretariat organization in providing support to the Vice President are viewed from the perspective of the McKinsey 7S Framework (2015-2019 study). The purpose of this study is to analyze the performance factors of the Setwapres in providing support to the Vice President. Specific research that discusses the performance factors of public organizations in charge of providing support to stakeholders. Very Very Important Person (VVIP) is still minimal, especially in presidential institutions. Therefore, through the analysis of performance factors, it is expected to be able to improve the performance of the Setwapes organization.

\section{RESEARCH METHOD}

The location of this research was in the Setwapres, whereas the Vice President's first support system, researchers found a decrease in performance results in the 2015-2019 period. It was a real problem within the organization that deserves further investigation.

This research was descriptive research with a qualitative approach. A qualitative process is carried out by looking for the cause of an impact produced by an event. The study was intended to dig up information and explain how the performance factors of the Setwapres were.

Data collection techniques were primary data through in-depth interviews and secondary data in the form of documentation studies. The selection of informants was made through purposive sampling (determination with specific considerations). Where the selected informants were considered to have a strategic role with the events studied and participated directly so that the truth could be trusted. The informants were the Deputy for Administration, Head of the Protocol and Housekeeping Bureau, Middle Policy Analyst, Head of the Household Section, Head of Protocol Section, Middle Expert Budget Analyst, Middle Expert Apparatus Human Resources Analyst, Young Expert Computer Administrator, and Head of the Vice President's Palace Subdivision. Documentation studies consist of books, scientific journals, agency documents, and other forms of supporting articles.

Data processing procedures were (1) data reduction by classifying, removing unnecessary data, and organizing; (2) data presentation in which data in writing, tables, excerpts from interviews are summarized systematically so that they are easy to understand; (3) data verification through triangulation in order to obtain the 
correct conclusions. The source triangulation was carried out by comparing data from interviews with one informant with other informants and with related documents.

\section{RESULT AND DISCUSSION}

This research found that the Setwapres had prepared a Strategic Plan (Rienstra) as an organizational strategy. In addition, there are 194 Standard Operating Procedures (SOP) and 102 Service Standards (SP) as guidelines for carrying out duties and functions. Meanwhile, a review of the documentation shows that in 2011 the Setwapres made a downsizing of the structure from 235 to 216 structural positions. Furthermore, in 2015, there was another change, namely the reduction of one echelon I place, which had implications for the loss of a number of structural positions under it. In total, the Setwapres decreased from 216 to 194 structural classes.

This research illustrated that Setwapres has tried to achieve a lean organizational structure. Remembering in(Haning, 2018)It is said that bureaucratic problems include fat organizational structures and tend to be inefficient. However, the results of the interview show that there is still a shortage of staff in several positions and hard skills that have not been maximized. The analysis is based on seven variables of the 7S McKinsey Framework as follows.

\section{Strategy}

The right strategy was clearly defined, long-term in nature, reinforced by the vision, mission, and values of the organization (Ravanfar, 2015). The system should include the allocation of resources, time span, and efforts to achieve goals. Indicators in the strategy include employee involvement in the formulation process, the suitability of the work plan, and evaluation.

The process of formulating the Setwapres Strategic Plan had involved employees with a bottom-up approach. Meanwhile, the preparation of work programs uses a top-down approach. However, regarding the suitability of the work plan, the results of the study found that the Strategic Plan did not include the Vice President's priority program. This has an impact on the activities of work units that are not entirely focused on the Vice President's priority programs. The strategic plan was considered to still concentrate on suitability in terms of tasks and functions. Therefore, programs and activities that were not appropriate result in performance outputs, and they are not in accordance with the preferences of the Vice President. It also had an impact on HR support and inappropriate budgets. Whereas as the Vice President's first support system, Setwapres was different from other sectoral ministries were activities,

The results of this research also found that the Rienstra evaluation activities were still limited to changes in performance targets. Ideally, when there was a change in the Vice President's preferences, the Strategic Plan must immediately adjust.

\section{Table 3. Strategy Aspect Findings}

Field Finding

Source of Problem

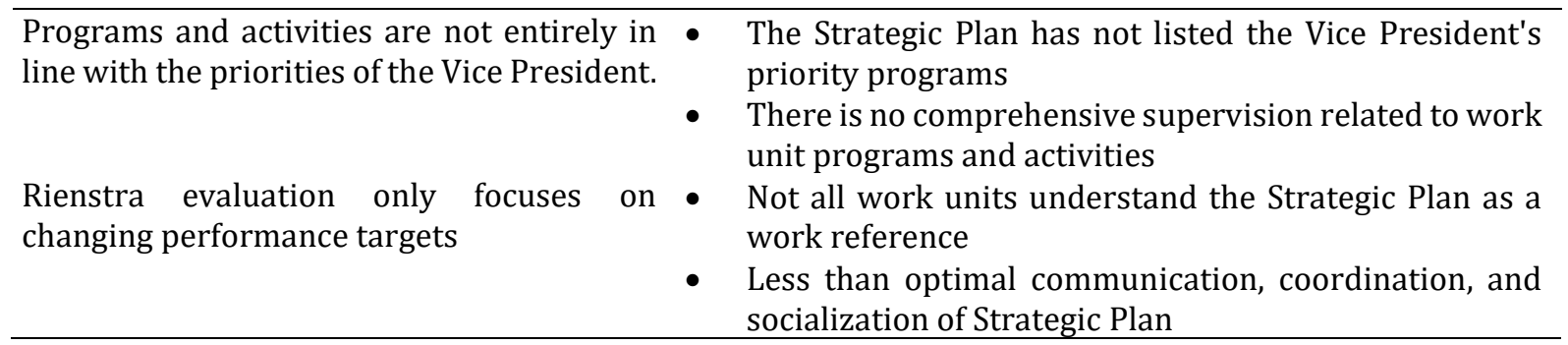

Source: has been reprocessed 


\section{Structure}

One of the factors that influenced the success of the strategy was the organizational structure (Okumus, 2003) (Rachman \& Huseini, 2019). Whereas(Kocaoglu \& Demir, 2019) argue that structure was used to evaluate organizational performance. The structure was defined as the basis of specialization and coordination that is influenced by the strategy, size, and diversity of the organization (Alshaher, 2013).

The indicator nature of the organizational structure was the clear division of tasks, functions, and responsibilities. Related to this, the clarity of duties and procedures has been stated in
Permensesneg number 3 of 2015 . However, there was still overlapping of tasks between work units, especially in the Deputy for Substance. It was because the government programs handled by the Vice President are broad and diverse. Especially with the role of the Vice President as a policy recommendation, de-bottlenecking, and also coordinator so that the task linkages between work units are still found to intersect with each other.

Another indicator was the existence of coordination mechanisms and patterns of interaction between units within the organization. The study found that coordination and interaction between work units had gone well.

Table 4. Findings of Structure Aspects

\begin{tabular}{|c|c|}
\hline Field Finding & Supporting Resources \\
\hline Gradual restructuring & $\begin{array}{l}\text { - There is a goal towards the lean organization } \\
\text { - Adjustment of the structure to the characteristics of } \\
\text { the Vice President }\end{array}$ \\
\hline $\begin{array}{l}\text { There is overlapping of tasks between work } \\
\text { units and uneven allocation of functions } \\
\text { because it depends on the focus of the Vice } \\
\text { President's program }\end{array}$ & $\begin{array}{l}\text { - The strategy is carried out by utilizing existing human } \\
\text { resources, establishing collaboration, and forming a } \\
\text { work team in the preparation of policy analysis }\end{array}$ \\
\hline $\begin{array}{l}\text { Suitable coordination mechanism and } \\
\text { interaction pattern between work units }\end{array}$ & $\begin{array}{l}\text { - There are meetings between work units on a regular } \\
\text { basis to equalize perceptions and find solutions to } \\
\text { problems }\end{array}$ \\
\hline
\end{tabular}

Source: has been reprocessed

\section{Systems}

McKinsey's 7Frameworkrk explained the system includes organizational ways and processes to complete work effectively and efficiently, which consists of indicators of the existence of SOPs, full implementation of SOPs including monitoring and evaluation, and the presence of ICT support.

Amare (2012) stated that there was an SOP to minimize errors that might occur. The implementation of the SOP was expected to be able to guarantee the quality of service according to the needs and expectations of the user. However, in practice, the full implementation of SOPs was challenging to carry out in the sudden activities of the Vice President. Meanwhile, SOPs for administrative activities had not been fully implemented accordingly. In addition, evaluations for improving SOPs had not been carried out on an ongoing basis.

Another finding was that the performance of employees had been supported by ICT from various aspects, from correspondence to file sharing. However, the use of ICT had not been optimal. (Wiyati \& Kartika, 2019)explained that in order to determine the success of ICT implementation, it was necessary to evaluate so that the organization can know the impact and benefits. However, research had not found any evaluation of the use of applications in the Vice President Secretariat.

Table 5. System Aspect Findings 


\begin{abstract}
Implementing SOPs for sudden activities is - There is a demand always to be fast and precise difficult to implement fully

The implementation of SOPs for administrative activities has not been fully implemented properly.

- Socialization and monitoring of SOPs and SPs are not comprehensive and are not carried out routinely.

- There are no facilities that make it easier for employees to understand SOPs and SP.

The utilization of information technology is not optimal

- There is a limited functional capacity in the system

- There is no integrated system, so that there are similar functions in several applications

- There has been no evaluation of each use of the application

Source: Reprocessed
\end{abstract}

\section{Style}

The style was a leadership style related to how to influence, motivate and help employees to work. The leadership style in this research was the leadership style of high-level Echelon I and II positions. There were six categories of leadership styles, one of which was a democratic leader who has the characteristics of respecting opinions, providing opportunities to implement creative ideas, and giving praise and criticism objectively. Khajeh, 2018). The indicators in leadership were attention and motivation, good communication, and leadership involvement.

The factual conditions had shown there was good attention and motivation from superiors to subordinates, such as equal opportunities in training and continuing education. In addition, communication went well through job evaluation meetings and direct contact, especially on the sudden activities of the Vice President.

In addition, all echelon I and II leaders were also directly involved in providing support to the Vice President. At the deputy of substance, the leaders were always directly involved in the process of formulating policy analysis. They were starting from coordination, monitoring to the revision process, and discussion. The same applied to protocol and housekeeping support, where the leadership role was huge in monitoring and supervising the Vice President's program. In almost every Vice President event, Echelon I leaders started from the Head of the Vice President's Secretariat, Deputy Leaders, to the Head of the Bureau went directly to the field to ensure that there were no technical problems.

Table 6. Findings of Style. Aspects

\begin{tabular}{lll}
\hline \multicolumn{2}{c}{ Field Finding } & \multicolumn{1}{c}{ Supporting Resources } \\
\hline $\begin{array}{l}\text { Democratic leadership } \\
\text { style }\end{array}$ & $\bullet$ & $\begin{array}{l}\text { The division of tasks, especially protocol support, which takes into account } \\
\text { the condition of each employee }\end{array}$ \\
& $\bullet$ & Equal opportunity to participate in training and continue education level \\
& - & Good communication through periodic and in-person work evaluation \\
meetings & Direct involvement of the leadership in carrying out the task of providing \\
& support to the Vice President
\end{tabular}

Source: has been reprocessed

\section{Staff}

The staff element related to the type and number of human resources needed and how they were recruited, trained, motivated, and rewarded (Ravanfar, 2015). Indicators of the staff were a recruitment 
system that was in accordance with the needs of the organization, the placement of human resources according to their educational background and skills, as well as a reward and punishment system.

The current obstacle was the ASN HR recruitment system which refers to the Ministry of State Secretariat's master policy. This research had an impact on the number of formation requirements that do not always match the needs. In addition, there was no longer a recruitment system policy for ASN at the high school level, which has an impact on the lack of ASN human resources in charge of providing support for household services. Therefore, the Vice President Secretariat was assisted by non-ASN (outsourced) staff. The placement of ASN human resources was also not entirely in accordance with their educational background and skills. This research indicated that the suitability of the career pattern was not optimal because most of it is still based on rank requirements.

Regarding the indicators of the reward and punishment system, the study found that the performance appraisal was already based on ICT. However, it was considered not optimal because there is no mechanism for a reward and punishment system that was directly linked to the achievement of performance targets. Performance appraisal was still limited to calculating attendance for performance allowances.

Table 7. Findings of Staff Aspect

\begin{tabular}{ll}
\hline \multicolumn{1}{c}{ Field Finding } & \multicolumn{1}{c}{ Source of Problem } \\
\hline $\begin{array}{l}\text { Lack of ASN human resources in charge of providing } \\
\text { support for household services to the Vice President }\end{array}$ & $\begin{array}{l}\text { The ASN HR recruitment system refers to the } \\
\text { Ministry of State Secretariat's policy. } \\
\text { There is no longer a recruitment system policy } \\
\text { for ASN at the high school level. } \\
\text { Assessment or screening is still limited. }\end{array}$ \\
$\begin{array}{l}\text { Carrying out duties as a waiter for the Vice President } \\
\text { assisted by non-ASN assistants (outsourcing staff) } \\
\text { carries a reasonably high risk. }\end{array}$ & $\begin{array}{l}\text { Most of them are still based on rank } \\
\text { The suitability of career patterns is not optimal. }\end{array}$ \\
& $\begin{array}{l}\text { requirements and not in accordance with } \\
\text { educational background. }\end{array}$ \\
\hline
\end{tabular}

Source: has been reprocessed

\section{Skills}

The quality of human resources was influenced by the skills they have. Skills consist of hard skills, which refer to technical skills through training, education, or learning in the workplace, and soft skills, which refer to personality traits (Ahmed et al., 2012) in (Setiana et al., 2019). Indicators in skills were the suitability of skills with organizational needs and the usefulness of training.

Documentation review showed that the highest number of human resource education levels were undergraduate education levels (27.25\%), masters (26.16\%), and senior high schools (23.71\%). However, the factual conditions showed that the skills of the employees were not entirely in accordance with the needs of the organization. An example was the lack of employee skills related to the provision of meals and table settings. It was due to the lack of employees with appropriate educational backgrounds, such as the culinary arts department.

Meanwhile, providing support for policy analysis was a dynamic nature of work. It required the capacity of employees to be able to prepare meeting materials and relevant study results. Employees must be able to think analytically, tactically, update on developing dynamics, be broad-minded and responsive. However, the obstacle faced was the lack of skills to carry out these functions. Meanwhile, skill improvement through training was 
considered not optimal where specific training is only a little and does not continue every year.

Table 8. Findings of Skill Aspect

\begin{tabular}{lll}
\hline \multicolumn{1}{c}{ Field Finding } & \multicolumn{1}{c}{ Source of Problem } \\
\hline $\begin{array}{l}\text { Lack of employee skills, especially in-household } \\
\text { support }\end{array}$ & $\bullet \quad$ High school level HR education background \\
& Human resources with the appropriate educational \\
background are still limited. & Skills are acquired more by learning by doing. \\
Not optimal skills employees in policy analysis & $\bullet \quad$ Lack of supportive training \\
support to the Vice President \\
$\begin{array}{l}\text { Most types of training only support general } \\
\text { competencies such as English language skills, } \\
\text { work, computers. }\end{array}$
\end{tabular}
Source: has been reprocessed

\section{Shared Values}

Kaplan (2005) stated that and professionalism of ASN, maintaining a organizational culture was the primary work culture has been carried out through value in the organization that played a role the establishment of Integrity Zones and in guiding the vision, mission, and value the selection of Civil Apparatus Role statement. The indicator was the existence Models. Meanwhile, to create a positive of a co-created organizational culture and work culture, activities were carried out supervision of corporate culture.

Vice President Secretariat itself had formulated a value system consisting of professional, transparent, accountable, excellent, integrity, effective and efficient values. In addition, internalization activities as well as strengthening work culture had been carried out correctly. For example, in order to increase the integrity with the "Reprimand, Greet, Greeting" movement, the application of an energysaving culture, and also a cleaning competition. Even though monitoring and supervision had not been fully optimal, the research assesses that the Vice President Secretariat had a commitment to change the mindset and work culture for the better.

Table 9. Findings of Shared Values

\begin{tabular}{|c|c|}
\hline Field Finding & Supporting Resources \\
\hline $\begin{array}{l}\text { There is an organizational } \\
\text { culture }\end{array}$ & $\begin{array}{l}\text { - Has formulated the Vice President Secretariat values } \\
\text { - There are internalization, socialization, and strengthening work } \\
\text { culture activities through the work program of the Bureaucratic } \\
\text { Reform Team in the field of Change Management. }\end{array}$ \\
\hline $\begin{array}{l}\text { Have a commitment to change } \\
\text { the mindset and work culture } \\
\text { for the better }\end{array}$ & $\begin{array}{l}\text { - Fast coordination between work units, mainly so that there is never a } \\
\text { delay, there is teamwork that can speed up the process of formulating } \\
\text { policy analysis, as well as the role of leaders who are often directly } \\
\text { involved in carrying out daily tasks that illustrate professional values } \\
\text { and integrity }\end{array}$ \\
\hline
\end{tabular}

Source: has been reprocessed

\section{CONCLUSION}

As an organization that had the task of being attached to the Vice President, it absolutely requires the capability and flexibility of the Secretary of Vice President to support the dynamic execution of the 
duties of the Vice President. The position of Secretary of Vice President was very strategic to improve organizational performance in realizing excellent service. The results of this study concluded that the supporting factors were aspects of structure, style, and shared values. While the inhibiting factors were aspects of strategy, system, staff, and skills. Based on this research, several efforts that we're able to be made to improve the performance of the Secretary of Vice President included the need for comprehensive monitoring from the leadership regarding the program activities of all work units so that they were in accordance with and in line with the Vice President's priority programs, evaluation and improvement of Standard of Producers in accordance with the new working relationship more functional,

\section{REFERENCES}

Alshaher, A.A. (2013). The McKinsey 7S Model Framework For E-Learning System Readiness Assessment. International Journal of Advances in Engineering \& Technology. 6(5): 9744-9744.

Amare, G. (2012). Reviewing the values of a standard operating procedure. Ethiopian Journal of Health Sciences. 22(3): 205-208.

Daft, R. L. (2010). Organization Theory and Design. Tenth edition. South-Western: Cengage Learning.

Dewi, R.R., \& Kurniawan, T. (2019). Manajemen Perubahan Organisasi Publik: Mengatasi Resistensi Perubahan. Natapraja. 7(1): 5372.

Fahrudin, V., Nurwati, \& Saleh, S. (2019). Pengaruh Perubahan Organisasi Pada Kinerja Pegawai Dengan Budaya Organisasi Sebagai Variabel Mediasi. JUMBO (Jurnal Manajemen, Bisnis, Dan Organisasi) Universitas Halu Oleo. 3(3): 69-83.

Garbrah, T. F. G.-, Binfor, F., \& Binfor, F. (2013). An Analysis of Internal Environment of a Commercial-oriented Research Organization: Using Mckinsey 7S Framework in a Ghanaian Context. International Journal of Academic Research in Business and Social Sciences. 3(9): 87-103.
Haning, M. T. (2018). Reformasi Birokrasi di Indonesia: Tinjauan Dari Perspektif Administrasi Publik. Jurnal Analisis Kebijakan Dan Pelayanan Publik. 4(1): 25-37.

Kaplan, R. S. (2005). How the balanced scorecard complements the McKinsey 7-S model. Emerald Group Publishing Limited. 33(3): 41-46.

Khajeh, E. H. Al. (2018). Impact of Leadership Styles on Organizational Performance. Journal of Human Resources Management Research.

Kocaoglu, B., \& Demir, E. (2019). The use of McKinsey s 7Frameworkrk as a strategic planning and economic assessment tool in the process of digital transformation. Pressacademia. 9(9).

Laporan Kinerja Sekretariat Wakil Presiden Tahun 2019.

Masfi, A., Sukartini, T., \& Hidayat, A. A. A. (2020). Performance improvement model utilizing the McKinsey 7S approach for public health centers in Sampang regency of Indonesia. International Journal of Scientific and Technology Research. 9(3): 5073-5076.

Peraturan Menteri Sekretaris Negara Nomor 3 Tahun 2015 tentang Organisasi dan Tata Kerja Kementerian Sekretariat Negara

Peters, T. J., \& Waterman, R. H. J. (2004). In Search of Excellence. Lessons from America's Best-Run Companies. First HarperBusiness Essential edition. New York: HarperCollins Pubisher Inc.

Rachman, F., \& Huseini, M. (2019). Faktor-faktor yang Mempengaruhi Implementasi Kebijakan Pengembangan Jaringan Kantor PT Bank Negara Indonesia (Persero) Tbk. Jurnal Riset Perbankan Manajemen Dan Akuntansi. 3(1): 15-39.

Ravanfar, M. M. (2015). Analyzing Organizational Structure based on the 7s model of McKinsey. International Journal of Academic Research in Business and Social Sciences. 5(5).

Setiana, S. M., Setiawati, L., \& Mustaqim, M. (2019). Hard skills versus soft skills: How do they affect different job types of Japanese language graduates? International Journal of Learning, Teaching and Educational Research. 18(11): 176-192.

Undang-Undang Dasar Negara Republik Indonesia Tahun 1945.

Wiyati, R. K., \& Kartika, N. L. A. (2019). Evaluasi Penerapan Sistem Informasi Absensi Online Dengan Hot Fit Model. Jurnal Teknologi Informasi Dan Komputer. 5(1). 